\title{
Primary bilateral guttural pouch empyema in a two-month-old foal
}

\author{
Empiema de bolsa gutural primário bilateral em potro de dois meses
}

\section{Deborah Penteado Martins Dias ${ }^{I^{*}}$ Nara Saraiva Bernardi ${ }^{I}$ Daniela Junqueira de Queiroz}

\section{- NOTE -}

\begin{abstract}
The present report describes a 2-month-old foal which signs of respiratory infectious disease, bilateral retropharyngeal swelling and nasal mucopurulent discharge, suggesting guttural pouch empyema. The owners reported that the foal lived in a herd that experienced an outbreak of strangles. Foals younger than 3 months are usually protected against infectious diseases, however in this case, the foal was exposed to an environment heavily populated by Streptococcus equi equi during the outbreak of strangles. Although uncommon in such young animals, the foal was infected and developed a primary bilateral guttural pouch empyema, without signs of lymph nodes alteration.
\end{abstract}

Key words: guttural pouch, horse, strangles, Streptococcus equi.

RESUMO

O presente trabalho descreve o caso de um potro de dois meses de idade com sinais de infecção respiratória, distensão bilateral da região retrofaríngea e secreção nasal mucopurulenta, sugerindo empiema de bolsa gutural. Os proprietários relataram que o potro pertencia a uma tropa que havia sido acometida por garrotilho recentemente. Potros com menos de 3 meses de idade são normalmente protegidos contra as doenças infecciosas, no entanto, este potro foi exposto a um ambiente altamente contaminado por Streptococcus equi equi durante o surto de garrotilho. Embora incomum em animais tão jovens, o potro foi infectado e desenvolveu um empiema primário de bolsa gutural, não havendo sinais de acometimento dos linfonodos.

Palavras-chave: bolsa gutural, equino, garrotilho, Streptococcus equi.

Streptococcus equi subspecies equi are pathogenic for equids and an important cause of upper respiratory tract disease. The infection is transmitted by inhalation or ingestion of the organism eliminated in the mucopurent discharge from an infective animal (TIMONEY, 2004). S. equi equi do not colonize mucosal surface, but penetrates into deeper tissue and enters the lymph nodes of the head and neck (SWEENEY et al., 2005). Clinical signs include fever, apathy, retropharyngeal lymph nodes abscessation and mucopurulent nasal discharge (AINSWORTH \& CHEETHAM, 2010). The disease is known as "strangles", in reference to suffocation, due to narrowing of the pharynx caused by enlargement of the retropharyngeal lymph nodes in severe cases (TAYLOR \& WILSON, 2006). Streptococcus equi equi accounts for most primary bacterial infections of the guttural pouch (GP) and lead to the development of an empyema (FREEMAN, 1980; PERKINS et al., 2003; PUSTERLA et al., 2006). Guttural pouch empyema is usually a consequence of upper repiratory tract infection (AINSWORTH \& CHEETHAM, 2010; FREEMAN \& HARDY, 2012). The infection can also be a complication of strangles, when abscessed retropharyngeal lymph nodes drain into the ipsilateral pouch (HARDY \& LÉVEILLÉ, 2003). Guttural pouch empyema is commonly observed in adult horses (HARDY \& LÉVEILLÉ, 2003; GERARD et al., 2006), while in foals, the most common disease of the GP is timpany (BLAZYCZEK et al., 2004). This report describes a case of a young foal diagnosed with a primary bilateral GP empyema.

A 2-month-old (112kg) Quarter Horse foal was referred for veterinary evaluation due

IDepartamento de Clínica e Cirurgia Veterinária, Faculdade de Ciências Agrárias e Veterinárias, Universidade Estadual Paulista Júlio de Mesquita Filho (UNESP), 14884-900, Jaboticabal, SP, Brasil. E-mail: deborah_dias@hotmail.com. *Corresponding author. Received 05.01.14 Approved 10.23.14 Returned by the author 02.18.15 CR-2014-0669.R1 
to respiratory distress. The owners reported that during the last 7 days the foal showed progressive enlargements caudally in the head, followed by nasal discharge. Suckling decreased and stopped 2 days prior to presentation. Birth and colostrum intake were normal for this foal. The owners also reported that the foal's dam, and other three mares of the same farm, had strangles recently and were not treated. All these animals were housed together in a large paddock, and its deworming and vaccination (against influenza viruses, encephalomyelitis, tetanus and rabies) statuses were up-to-date. Upon initial examination the foal was apathetic, dehydrated, tachycardic (180 beats per minute), mildly pyrexic at $39.6{ }^{\circ} \mathrm{C}$, and tachypneic (45 breaths per minute) accompanied by nostril flaring. Mucous membranes were congested and of a red color, capillary refill time was prolonged ( 3 seconds), facial artery pulse was weak and the extremities were cold. The foal presented with severe right and left retropharyngeal swellings (Figure 1A-B) that were painful on palpation and with a copious bilateral nasal mucopurulent discharge (Figure 1C). Cough and dysphagia were evident, and the foal showed extended neck carriage. Auscultation revealed tracheal mucus accumulation and abnormal lung sounds. The dam, referred with its foal, had the udder full of milk and showed a ruptured retropharyngeal abscess on the left side (Figure 1D). History and clinical signs suggested GP empyema and due to the severe bilateral distention leading to dyspnea, an emergency surgical drainage was recommended. A catheter was placed into the jugular vein, the foal received 5 liters of a solution containing $0.9 \%$ of $\mathrm{NaCl}$ and $5 \%$ of glucose, however it suddenly died during fluid administration. Necropsy was immediately performed and revealed the fullness of right and left GP by mucopurulent exudate, no signs of retropharyngeal abscesses, presence of mucous accumulation in the trachea and diffuse pulmonary congestion in the lungs suggesting pneumonia. A bacteriological study of purulent material identified Streptococcus equi strains.

The bilateral retropharyngeal distention, copious nasal mucopurulent discharge and the neck in extension are classic signs of GP empyema (FREEMAN \& HARDY, 2012), and for the present case these signs determined the diagnosis. The other clinical findings, such as depression, anorexia, tachycardia, tachypnea, congested mucous membranes, prolonged capillary refill time and pyrexia are commonly associated with respiratory tract infections (WILSON, 2003). The foal also presented with tracheal rattle, a common result of excessive mucous accumulation caused by diseases of the lower airways (PUSTERLA et al., 2006). These abnormalities could be associated with aspiration pneumonia secondary to dysphagia, as reported by WILKINS (2010). In cases of severe GP empyema dysphagia is a manifestation of cranial neuropathy (FREEMAN \& HARDY, 2012). The glossopharyngeal, vagus and hypoglossal nerves, which innervate muscles used in the swallowing process, are contained in a fold of the mucous membrane along the caudal wall of the GP medial compartment (CARMALT, 2002; BORGES \& WATANABE, 2011). This close anatomic relationship between GP and cranial nerves can lead to neurologic abnormalities in the presence of a disease, and mycosis is the most common injury associated with disturbances of cranial nerves (BORGES \& WATANABE, 2011). In the present case, although uncommon in cases of empyema (MODRANSKY, et al. 1982; HARDY \& LÉVEILLÉ, 2003), cranial nerves may have been affected by the compression within the pouch due to the high volume of exudate, matching the evolution of dysphagia. Upon first examination, the foal had swallowing difficulty and its dam udder was full of milk, suggesting reduced intake. Concerning the sudden death, it is known that bacterial pneumonia in foals may lead to the development of sepsis (WILSON, 2003; ROY, 2004) and severe sepsis is accompanied by multiple organ dysfunction syndrome due to factors including increased circulating levels of inflammatory mediators, hypotension and poor vascular perfusion (BONE et al., 1992). The foal had signs of septic shock, as lethargy, tachycardia, tachypnea, pyrexia, weak pulses and cold extremities as described by ROY, (2004). Probably the stress caused by physical restraint for catheter implantation and fluid administration, increased the tissues oxygen consumption, and the foal developed myocardial ischemia due to poor perfusion, followed by a cardiac arrest. Empyema in foals may be secondary to GP timpany (FREEMAN, 1980). However for the present case, this etiology was excluded because the owners did not report evidences of timpany during the onset of clinical signs. In the case of a timpany, the enlargement would be nonpainful, would appear shortly after birth, as the condition is congenital (BLAZYCZEK et al., 2004; FREEMAN \& HARDY, 2012), and the foal would not present signs of sepsis, since GP timpany is a non-infectious condition. Guttural pouch empyema following strangles is usually associated with abscessation and rupture of retropharyngeal lymph nodes into the pouch 


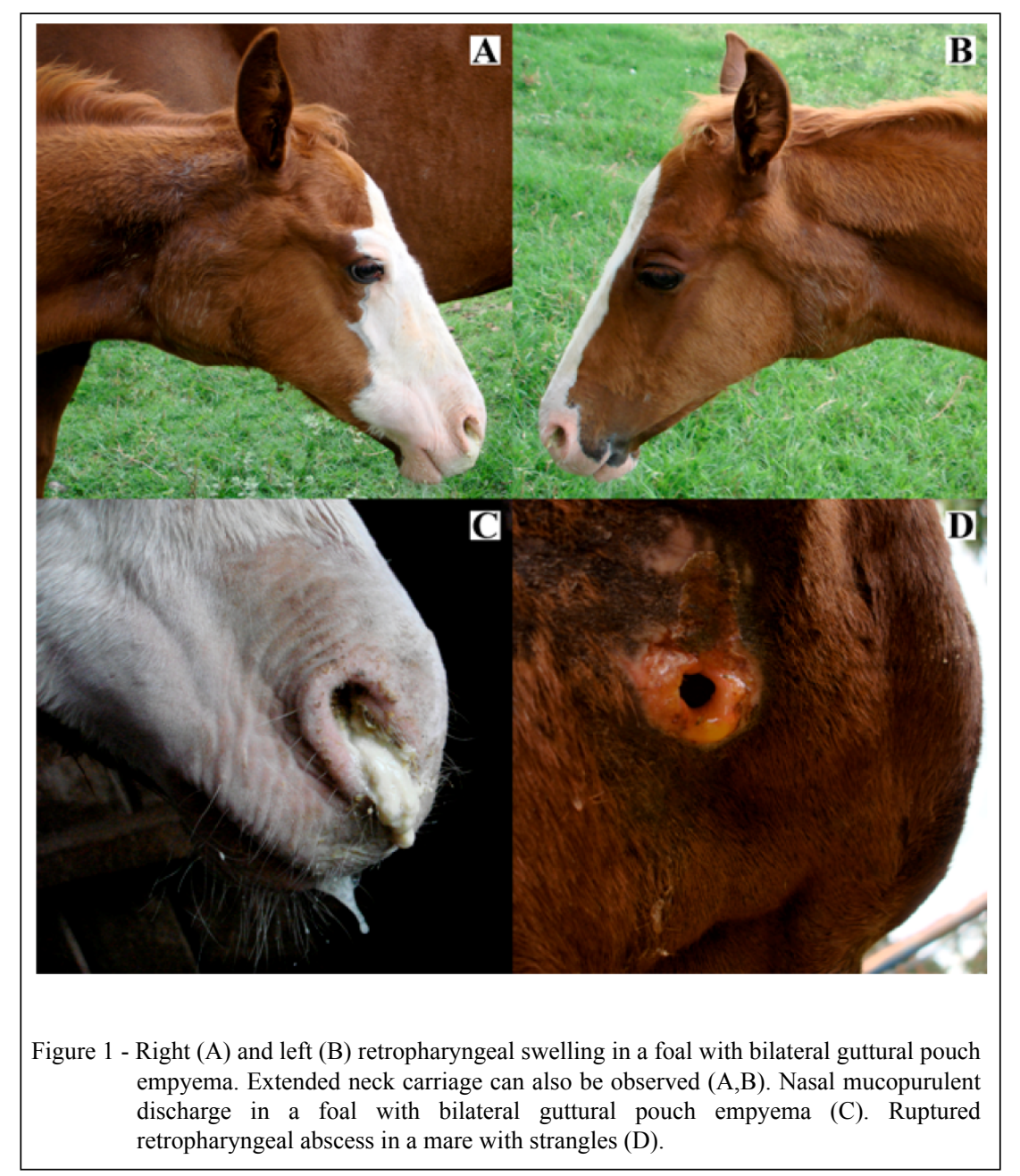

(HARDY \& LÉVEILLÉ, 2003). For this case, no signs of retropharyngeal lymph nodes infection were observed during necropsy. Thus, the foal did not develop strangles, and bacteria probably colonized the upper respiratory airways reaching the GP, according to the description of AINSWORTH \& CHEETHAM (2010) and FREEMAN \& HARDY (2012). However, development of any kind of infection in foals younger than 3 months is the exception rather than the rule. A foal is practically immunocompetent at birth, and its primary immune response confers protection for 2 weeks. During this lag time, the passive immunity acquired from colostrum is essential for preventing infection (GUIGÈRE \& POLKES, 2005). The colostral antibodies ingested during the first 24 hours of life reaches the nasopharyngeal mucosa providing protection (SWEENEY et al., 2005). The owners reported a normal foaling and normal colostrum ingestion. However, the foal's dam showed abscessation of the left retropharyngeal lymph node, showing that this mare was not stranglesresistant and therefore did not transfer adequate immunity to its foal. Pregnant mares must receive a vaccine booster a month before expected date of foaling (SWEENEY et al., 2005). Furthermore, the foal lived in a herd that was not vaccinated against strangles and was exposed to an environment heavily populated by Streptococcus equi subspecies equi during an outbreak of the disease. Therefore, although uncommon at the age of 2 months, the foal was infected and developed a primary GP empyema, without lymph nodes abscesses. Strangles is the most frequently diagnosed infectious disease of horses and causes significant welfare and economic impact in herds worldwide (WALLER, 2013) highlighting the importance of preventative methods including vaccination, and appropriate environmental and management changes to control outbreaks.

Ciência Rural, v.45, n.6, jun, 2015. 


\section{REFERENCES}

AINSWORTH, D.M.; CHEETHAM, J. Disorders of the respiratory system. In: REED, S.M. et al. Equine internal medicine. St. Louis: Saunders, 2010. Cap.9, p.290-371

BLAZYCZEK, I. et al. Retrospective analysis of 50 cases of guttural pouch tympany in foals. Veterinary Record, v.154, n.9, 261-264, 2004. Available from: <http://veterinaryrecord. bmj.com/content/154/9/261.full.pdf + html $>$. Acessed: April 2014. doi:10.1136/vr.154.9.261

BONE, R.C. et al. Definitions for sepsis and organ failure and guidelines for the use of innovative therapies in sepsis. The ACCP/ SCCM Consensus Conference Committee. American College of Chest Physicians/Society of Critical Care Medicine. Chest, v.101, n.6, 1644-1655, 1992. Available from: <http://journal.publications. chestnet.org/data/Journals/CHEST/21647/1644.pdf>. Acessed: April 2014. doi:10.1378/chest.101.6.1644.

BORGES, A.S.; WATANABE, M.J. Guttural pouch diseases causing neurologic dysfunction in the horse. Veterinary Clinics of North America: Equine Practice, v.27, 545-572, 2011 Available from: <http://www.vetequine.theclinics.com/article/ S0749-0739(11)00046-0/pdf>. Acessed: April 2014. doi:10.1016/j. cveq.2011.08.002

CARMALT, J. Guttural pouch diseases in the horse. Large Animal Veterinary Rounds, v.2, n.2, 1-6, 2002.

FREEMAN, D.E. Diagnosis and treatment of diseases of the guttural pouch (Part 1). Compendium on Continuing Education for Practicing Veterinarian, v.2, S3-S11, 1980.

FREEMAN, D.E.; HARDY, J. Guttural pouch. In: AUER, J.A.; STICK, J.A. Equine surgery. St. Louis: Elsevier Saunders, 2012. Cap.46, p.623-642.

GERARD, M.P. et al. Infections of the head and ocular structures in the horse. Veterinary Clinics of North America: Equine Practice, v.22, n.2, 591-631, 2006. Available from: $<$ http://www. vetequine.theclinics.com/article/S0749-0739(06)00010-1/pdf $>$. Acessed: April 2014. doi:10.1016/j.cveq.2006.03.009.

GUIGÈRE, S.; POLKES, A.C. Immunologic disorders in neonatal foals. Veterinary Clinics of North America: Equine Practice, v.21, n.2, 241-272, 2005. Available from: <http://www.vetequine. theclinics.com/article/S0749-0739(05)00021-0/pdf>. Acessed: April 2014. doi:10.1016/j.cveq.2005.04.004.

HARDY, J.; LÉVEILLÉ, R. Diseases of the guttural pouches. Veterinary Clinics of North America: Equine Practice, v.19, n.1, 123-158, 2003. Available from: <http://www.vetequine.
theclinics.com/article/S0749-0739(02)00070-6/pdf >. Acessed: April 2014. doi:10.1016/S0749-0739(02)00070-6.

MODRANSKY, P.D. et al. Dysphagia associated with guttural pouch empyema and dorsal displacement of the soft palate. Equine Practice, v.4, 34-38, 1982.

PERKINS, G.A. et al. Diagnosing guttural pouch disorders and managing guttural pouch empyema in adult horses. Compendium on Continuing Education for the Practicing Veterinarian, v.25, n. 12, 966-973, 2003.

PUSTERLA, N. et al. Diagnostic approach to infectious respiratory disorders. Clinical Techniques in Equine Practice, v.5, n.3, 174-186, 2006. Available from: <http://www.sciencedirect.com/ science/article/pii/S1534751606000278>. Acessed: April 2014. doi:10.1053/j.ctep.2006.03.012.

ROY, M.F. Sepsis in adults and foals. Veterinary Clinics of North America: Equine Practice, v.20, n.1, 41-61, 2004. Available from: <http://www.vetequine.theclinics.com/article/ S0749-0739(03)00076-2/pdf>. Acessed: April 2014. doi:10.1016/j. cveq.2003.12.005.

SWEENEY, C.R. et al. Streptococcus equi infections in horses: guidelines for treatment, control, and prevention of strangles. Journal of Veterinary Internal Medicine, v.19, n.1, 123134, 2005. Available from: <http://onlinelibrary.wiley.com/ doi/10.1111/j.1939-1676.2005.tb02671.x/abstract>. Acessed: April 2014. doi:10.1111/j.1939-1676.2005.tb02671.x.

TAYLOR, S.D.; WILSON, W.D. Streptococcus equi subsp. equi (Strangles) infection. Clinical Techniques in Equine Practice, v.5, n.3, 211-217, 2006. Available from: $<$ http://www.sciencedirect. com/science/article/pii/S153475160600031X>. Acessed: April 2014. doi:10.1053/j.ctep.2006.03.016.

TIMONEY, J.F. The pathogenic equine streptococci. Veterinary Research, v.35, n.4, 397-409, 2004. Available from: $<\mathrm{http}: / / \mathrm{www}$. vetres.org/articles/vetres/pdf/2004/04/V4403.pdf $>$. Acessed: April 2014. doi: $10.1051 /$ vetres:2004025.

WALLER,A.S. Strangles: taking steps towards eradication. Veterinary Microbiology, v.167, n.1-2, 50-60, 2013. Available from: <http:/ www.sciencedirect.com/science/article/pii/S0378113513002137>. Acessed: April 2014. doi:10.1016/j.vetmic.2013.03.033.

WILKINS, P.A. Disorders of foals. In: REED, S.M. et al. Equine internal medicine. St. Louis : Saunders, 2010. Cap.21, p.1311-1363.

WILSON, W.D. Foal pneumonia. In: ROBINSON, N.E. Current therapy in equine medicine. St. Louis: Saunders, 2003. Cap.12.8, p.666-674. 